\title{
An Analysis of Alternative Weighting System on the National Price Index in Tanzania: The Implication to Poverty Analysis
}

\author{
Adolf F. Mkenda \& Wilhelm Ngasamiaku ${ }^{1}$
}

\begin{abstract}
This paper set out to calculate and compare "plutocratic" inflation to "democratic" inflation in Tanzania using monthly price data from 2003 to 2006 and the 2000/2001 National Household Survey data with the view to assess their impact on the poor. The paper first compares national inflation for plutocratic weighted price index against the inflation based on democratic weighted price index. Then the paper calculates "plutocratic" and "democratic" inflation for poor households and compares this to the non-poor households. Finally, the paper calculates both the "plutocratic" and "democratic" inflation for the households in the lowest quintile of consumption and compare to similar inflation for the highest quintile.

The paper finds that the plutocratic weighted inflation tends to be more sensitive to the changes in the prices of goods that are mostly consumed by the rich, while the democratic weighted inflation tends to be more sensitive to changes in the prices of goods consumed by the poor. The paper further finds that inflation rates based on "plutocratic" weights is generally lower than the inflation rate based on "democratic" weight, suggesting that the official inflation rate, which is based on the plutocratic weighting system, understates the inflationary burden to the poor In particular, the democratic inflation is found to be more pro-poor than plutocratic inflation rate. For this reason, the paper recommends that "democratically weighted" inflation should be preferred to "plutocratic weighted" inflation.
\end{abstract}

Key Words: Tanzania, Africa, Inflation, Plutocratic Weights, Democratic Weights, CPI

\section{Introduction}

Inflation the world over is calculated from the consumer price index derived as a weighted average of prices of goods and services in a representative basket. Traditionally, the relative weight of a commodity in the consumer price index is the ratio of total expenditure on a given commodity over the total expenditure over all commodities by these households. Naturally this weight is obtained from household budgets of a representative sample of households. For example, the weight that sugar is assigned in the national consumer price index in Tanzania is the total household expenditures on sugar by the sample of representative households divided by total 
expenditures on all commodities by these households. This method of weighting has been dubbed "plutocratic" by Prais (1959).

Under plutocratic weighting method, commodities that draw larger budgetary share in rich households receive more weight, while commodities that take relatively larger budget share of poor households are assigned relatively less weight. In general therefore luxury goods tend to get larger weights in plutocratic method than goods that are necessities. Plutocratic weighting method has been called a "one dollar one vote" weighting scheme to emphasize the fact that households with larger expenditures tend to skew the relative weights of commodities in favour of their own expenditure patterns (Kokoski 2000).

The Consumer Price Index (CPI) weights need not necessarily be based on plutocratic scheme. Possible alternative weights can be obtained from the average household budget shares on each commodity. A weight that a commodity is assigned in the consumer price index can therefore be obtained from the average of the households' budget share that each household devote to the commodity. This method of weighting commodities in the price index has been dubbed a "democratic" weighting method, presumably because the pattern of each household consumption counts equally in calculating the weight assigned to a commodity; it is a "one household one vote” system (Kokoski 2000, Prais, 1959).

The inflation rates calculated from the plutocratic weighted CPI will not differ from the one calculated from the democratic weighted CPI if the price of each commodity change by the same amount. Equally, if households have similar expenditure patterns the inflation rates will remain the same whether the CPI is democratically weighted or plutocratically weighted.

Needless to say, households do not have identical expenditure patterns, and rates of changes in prices across commodities are hardly identical. It is obvious therefore that inflation rates will differ depending on whether the CPI is plutocratic or democratic weighted. However the magnitude of the difference between the two inflation rates is not obvious. Such difference, which has been dubbed a plutocratic gap (see for example Izquierdo et al, 2003), will depend on the extent that households' expenditure pattern is a function of household incomes and the degree of inequality across households.

A significantly large plutocratic gap is an indication that rich households have expenditure pattern that is significantly different from the poor households and that there is a significant inequality across households. More importantly, a large plutocratic gap would signify that "democratic" weighted inflation reflects the burden of inflation on the poor more than "plutocratic" inflation does. Inflation has been found to inflict heavier burden to the poor than to non-poor even when measured with plutocratic weights (see for example Easterly and Fischer 2000). If a significant plutocratic gap is found to exist it would mean that inflation is even more burdensome to the poor than is generally reflected in the CPI. 
This paper compares "plutocratic" inflation to "democratic" inflation in Tanzania using monthly price data from 2003 to 2006 and the 2000/2001 National Household Survey data. The paper first compares national inflation for plutocratic weighted price index against the inflation based on democratic weighted price index. Then the paper calculates "plutocratic" and "democratic" inflation for the "officially" poor households and compares this to the non-poor households. Finally, the paper calculates both the "plutocratic" and "democratic" inflation for the households in the lowest quintile of consumption and compare it to similar inflation for the highest quintile.

\section{Theoretical Framework}

The consumer price index may be used to assess changes in the cost of fixed basket of goods or for assessing changes in the general welfare. The purpose of constructing the CPI and the manner that one interprets it is a matter of political economy. In practice the CPI has been calculated and interpreted in terms of a measure of changes in the cost of fixed basket of goods rather than as a measure of welfare changes mainly because of the difficulty of making welfare inference from the price index data (see for example Prais (1959), Diewert (2001), Hulten (2004), Boskin et al (1998)).

The connection between changes in the general price level and the welfare can be illustrated using indifference curves. Assume that there are two commodities only, $x$ and $y$. If a household initially consume bundle $\left(x^{1}, y^{1}\right)$ it would attain welfare level captured by the indifference curve $\mathrm{U}^{1}$.

If income of the household remains constant, an increase in the prices of both commodities would make bundle $\left(x^{1}, y^{1}\right)$ unaffordable to the household. The consumption of both commodities would be reduced to a new bundle $\left(x^{2}, y^{2}\right)$ as shown in Figure 1, which means that the household welfare decreases from $\mathrm{U}^{1}$ to $\mathrm{U}^{2}$. It is not difficult therefore to make welfare inference where prices of all commodities change in the same direction

Changes in the general price level as captured by the changes in the general price index does not lend itself easily for welfare inference because prices do not necessarily change in the same direction and households are heterogeneous. Pollak (1980) among others, have shown how the group price index can be constructed for welfare inference. 
Figure1: Illustration of Changes in Prices and Welfare

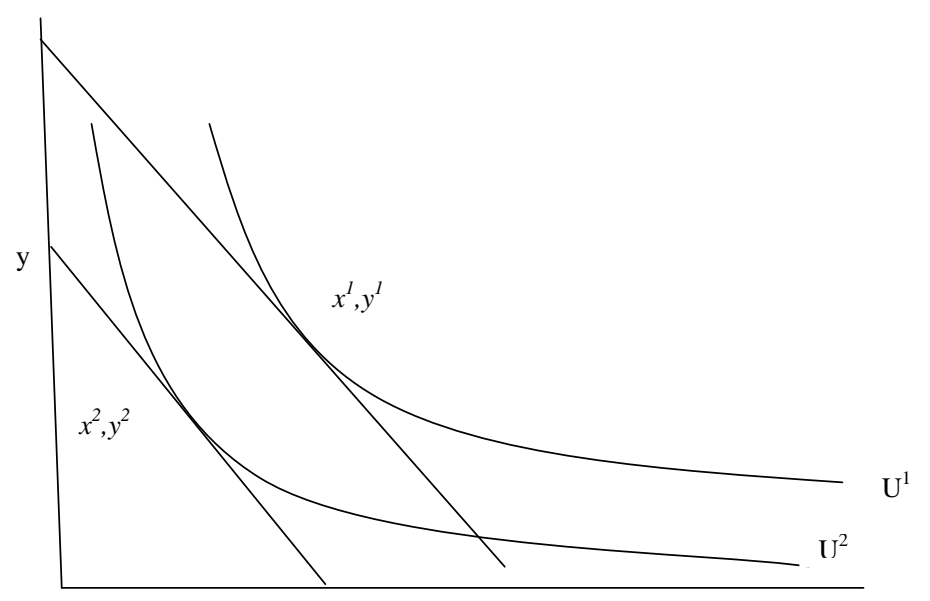

Prais (1959) and Nicholson (1975) have shown that the conventional approach for constructing consumer price index is likely to understate the welfare loss that the poor suffer from inflation. The bone of contention is the manner that weights are generated for constructing the price index. On one hand, weights of commodities in the price index can be obtained from the aggregate share of each item over the total expenditure on commodities. This kind of weight has been dubbed by Prais (1959) as plutocratic weight, because such weighting method is likely to make CPI more responsive to the price of commodities consumed by the rich than to the price of goods consumed by the poor.

The plutocratic weights is given as follows: $w_{i}^{p}=\frac{\sum_{h=1}^{H} e_{i}^{h}}{\sum_{i=1}^{n} \sum e_{i}^{h}}$, where $e$ is the

expenditure on commodity $i$ by the household $h$, for households $h=1,2, \ldots, H$, and commodities $i=1,2, \ldots . ., n$.

For example, using hypothetical data from Table 1, the plutocratic weight for food is given as follows;

$$
\sum \frac{60+50+30}{60+40+30+70+50+10+20+20+30+5+5+10}=0.4
$$

The alternative to the plutocratic weight is the democratic weight, which is given as follows: 


$$
w_{i}^{p}=\frac{1}{H} \sum_{h=1}^{H}\left[\frac{e_{i}^{h}}{\sum_{i=1}^{n} e_{i}^{h}}\right]
$$

The hypothetical data in Table 1 can be used to illustrate the way that democratic weight is calculated. The weight for food will be given as follows:

$\sum\left(\frac{60}{\sum(60+40+30+70)}\right)+\left(\frac{50}{\sum(50+10+20+20)}\right)+\left(\frac{30}{\sum(30+5+5+10)}\right)=0.46^{\prime}$

To examine further the difference between plutocratic weighted price index against the democratic weighted price index, we assume that in the base period of the hypothetical data in Table 1 prices were as follows: $\{$ food, drinks, clothes, others $\}=\{10,15,20,10\}$ and let the current prices for these commodities be $\{$ food, drinks, clothes, others $\}=\{15,10,25,15\}$. The Laspeyres price index is given as follows:

$\sum w_{i}^{0}\left(\frac{P_{i}^{t}}{P_{i}^{0}}\right)$, such that $\sum w_{i}^{0}=1$

Table 1: Hypothetical Expenditure Data with Alternative CPI Weights

Total

HHID Group Value Household Plutocratic Democratic
Consumption

\begin{tabular}{lccccc}
\hline 1 & Food & 60 & & 0.400 & 0.467 \\
1 & Drinks & 40 & & 0.157 & 0.133 \\
1 & Cloths & 30 & & 0.157 & 0.150 \\
1 & Others & 70 & 200 & 0.286 & 0.250 \\
2 & Food & 50 & & 0.400 & 0.467 \\
2 & Drinks & 10 & & 0.157 & 0.133 \\
2 & Cloths & 20 & & 0.157 & 0.150 \\
2 & Others & 20 & \multirow{2}{*}{100} & 0.286 & 0.250 \\
3 & Food & 30 & & 0.400 & 0.467 \\
3 & Drinks & 5 & & 0.157 & 0.133 \\
3 & Cloths & 5 & & 0.157 & 0.150 \\
3 & Others & 10 & 50 & 0.286 & 0.250 \\
\hline
\end{tabular}

Key: HHID=Household Identity Number

The price index based on plutocratic weights is given as follows:

$0.4\left(\frac{15}{10}\right)+0.157\left(\frac{10}{15}\right)+0.157\left(\frac{25}{20}\right)+0.286\left(\frac{15}{10}\right)=1.33$. In contrast, democratically 
weighted Laspeyres price index is given as follows:

$0.467\left(\frac{15}{10}\right)+0.133\left(\frac{10}{15}\right)+0.150\left(\frac{25}{20}\right)+0.250\left(\frac{15}{10}\right)=1.35$

The plutocratic gap (see Ley, 2002, Izquierdo et al, 2003) in the measurement of price index here is given by $1.33-1.35=-0.02$. This gap seems to be rather small, but it is important to note that the democratic weights and plutocratic weights are not very different in the hypothetical data. The magnitude of plutocratic gap would depend on three things. First, the degree to which rate and direction of changes differ across prices. The second is the degree to which expenditure patterns differ across households and such a difference is a function of the income of the household. Lastly the degree of inequality across household is directly related to the plutocratic gap.

\section{Calculating CPI in Tanzania-Basic Formulae and Data}

Price data is collected on monthly basis for a 212 different items in 20 regional main urban centres of Tanzania ${ }^{2}$. The data is aggregated at 5 levels. The most elementary level of aggregation, level 5, has 212 expenditure items. Typically, the levels of hierarchical aggregation are as shown in Table 2.

Table 2: Products Aggregation and Classification Structure

\begin{tabular}{|c|c|c|c|}
\hline LEVEL & $\begin{array}{c}\text { GENERAL } \\
\text { NOMENCLATURE }\end{array}$ & $\begin{array}{c}\text { CPI MANUAL } \\
\text { NOMENCLATURE }\end{array}$ & EXAMPLES 1 \\
\hline 6 & overall & $\begin{array}{c}\text { total } \\
\text { index }\end{array}$ & All commodities \\
\hline 5 & group & major group & food \\
\hline 4 & class & product groups & $\begin{array}{c}\text { cereal and } \\
\text { cereal products }\end{array}$ \\
\hline 3 & subclass & product sub groups & rice \\
\hline 2 & $\begin{array}{l}\text { subclass } \\
\text { by oulet }\end{array}$ & expenditure item & $\begin{array}{l}\text { rice (shops) } \\
\text { rice (open market) }\end{array}$ \\
\hline 1 & $\begin{array}{l}\text { representative } \\
\text { product }\end{array}$ & varieties & -white rice \\
\hline
\end{tabular}

A standard aggregation and classification structure known as the Classification of Individual Consumption according to Purpose (COICOP) has been adopted by many countries. Tanzania however does not use COICOP as yet; the difference between the Tanzanian classification of consumption items and COICOP is briefly explained in Appendix 1. The Consumer Price Index in Tanzania is based on twelve groups of consumption items (level 5 in Table 2). These groups are (i) Food, (ii) Drinks

Tanzania had 20 regions until recently. A new region was recently created but this has not yet been included separately in the price data. 
and Tobacco (iii) Clothing and Footwear (iv) Rents (v) Fuel, Power and Water (vi) Furniture and Household Equipment (vii) Household Operations and Maintenance (iix) Personal Care and Health (ix) Recreation and Entertainment (x) Transport (xi) Education and (xii) Miscellaneous Goods and Services.

The steps for calculating the price index in Tanzania follows the outline given in the user manual of the Consumer Price Index Compilation Model, an Excel add-in based Visual Basic for Application program developed by the IMF. The first step in calculating the consumer price index is to generate short term price relatives of the variety of items (level 1) at the regional level. This is done for the 212 varieties of non-missing prices using the following formula;

$$
S T P R_{t \rightarrow t-1 ; j, i}=\frac{\prod_{v=1}^{V}\left(p_{t j i v}\right)^{1 / v}}{\prod_{v=1}^{v=V}\left(p_{t-1 j i v}\right)^{1 / v}}
$$

Where $p$ stands for the price, $t$ for time period, $i$ stands for the item, and $v$ stands for the variety (or specification). Variety here means the actual commodity or services whose price is collected. An item $i$ is a collection of varieties of similar characteristics. The short term price relative for the regions is aggregated using weighted average to get the national short term price relative. This is done for the non-missing prices and the weights are given by the regions' national share of expenditure on the item. The national STPR for item $j$ is thus obtained as follows: $\sum_{i=1}^{n} w_{j, i} * S T P R_{i}$, where $w_{i}$ is

the regional $i$ 's total expenditure on non-missing item divided by the national total expenditure on item $j$.

Once the price relatives of the elementary commodities are obtained, higher level indexes (level 2 and above) is obtained by $\operatorname{LTPR}_{t \rightarrow 0, j, i}=\left(w_{j, i}\right)\left(\operatorname{LTPR}_{t-1 \rightarrow 0, j, i}\right)\left(\operatorname{STPR} R_{t \rightarrow t-1, j, i}\right)$

where

$\operatorname{LTPR}_{t-1 \rightarrow 0, i}=\frac{p_{t-1, i}}{p_{t s}}$, and $\operatorname{LTPR}_{t-1 \rightarrow 0, i}$ is the long term price relative for the current period, and $w_{j, i} p_{\text {Psi }}$ the expenditure weight for item $i$ in region $j$. This exercise is carried out progressively from 2, to level 3 then level 4 to level 5 and finally the overall CPI is obtained. Missing price relatives are imputed using top-down approach such that missing price at level 1 is imputed from the index at level 2 and so on.

The household budget survey data provides the weights used in the calculation of price indices. As in many other countries, the weights are fixed and remain so for several years. The current expenditure weights in Tanzania are derived from the 2000/1 household budget survey data. Prior to the 2000/1 household budget survey data, national price index was based on expenditure weights from the 1991 
national household budget survey data. The monthly inflation series used in this paper therefore starts from 2003 to coincide with the price series that is based on the 2000/1 household budget survey, which is the latest survey that is used in calculating the expenditure weights ${ }^{3}$.

Price data for CPI is collected only from the selected urban centres from each of 20 administrative regions. Inflation figures therefore are only a reflection of changes in the price in the selected urban areas. There are two main weaknesses with this limited coverage of price data. The first is that the expenditure share used as weights in the CPI are only based on the household expenditures in the selected households. These expenditure shares are not necessarily representative of the actual household expenditures in these selected urban centres. This is because the sampling scheme in the 2000/1 household budget survey data is such that the data cannot be representative of the population at any unit that is smaller than the whole of administrative region.

The second weakness of collecting price data exclusively from the selected urban centres is that rural area in which more than 80 of the population live is excluded, thus majority of people are not really taken into account in the national inflation figures. This is quite a serious problem because rural households on average are poorer than urban households. For instance, 39\% of households in the rural areas are below the poverty line, compared to $18 \%$ in Dar es Salaam and $26 \%$ in other rural areas (URT 2002).

\section{Plutocratic versus Democratic CPI Weights in Tanzania}

Using the data and method explained in the previous section the official inflation figures are calculated using plutocratic weights. Table 3 compares the national plutocratic weights against the democratic weights by the main Tanzania CPI consumption groups. In this table, the Plutocratic weight for food items is 55.9, which is less than the weights of 65.4 obtained using the democratic approach. In general, the poor use a larger budget share on food than the rich. The fact that plutocratic method gives less weight to food than does the democratic method indicates that plutocratic method is less sensitive to the consumption pattern of the poor than the democratic method. The national average household food share from the 2000/01 household budget survey data is 65, where the rural area has a share of 67 and urban area of 59 (URT 2002). While these shares are also "democratic", they differ from the national democratic weights used in the CPI because CPI data, and the corresponding weights, are based on a different sample of data; the sample is restricted to regional urban headquarters only, and thus represents neither the national nor the overall urban areas.

The difference between the plutocratic weights and democratic weights is reflected in other consumption groups too. The most significant differences appear

Note that monthly inflation is obtained from the difference between the monthly price index of the given year minus the monthly price index of the same month in the preceding year divide by the current monthly index. The current base year in Tanzania's price index is 2001. This is the year with the latest household budget survey data. 
in the recreational and entertainment and also transportation and education, where the plutocratic weights are twice the democratic weights. Obviously, to the poor recreational and entertainment are luxuries that cannot be regularly, if ever, afforded. Transport expenditure to the rich is more pronounced because of the more extensive use of personal cars and the longer distance that the rich generally cover, where as the poor normally use public transport, which is cheaper, and are less mobile in general. The expenditure on education is also sensitive to one's income; the rich pay for expensive private education while the poor can only afford, if ever, highly subsidized public education.

Table 3: National Plutocratic vs Democratic Weights

\begin{tabular}{|c|c|c|c|c|}
\hline \multirow[t]{2}{*}{ GROUP } & \multicolumn{2}{|c|}{ PLUTOCRATIC WEIGHTS } & \multicolumn{2}{|c|}{ DEMOCRATIC WEIGHTS } \\
\hline & TOTAL - VALUE & WEIGHT & $\begin{array}{c}\text { AVERAGE - } \\
\text { VALUE }\end{array}$ & WEIGHT \\
\hline Food & 36,753,351,927.04 & 55.9 & $4,152.6$ & 65.4 \\
\hline $\begin{array}{l}\text { Drinks and } \\
\text { tobacco }\end{array}$ & $4,538,873,401.15$ & 6.9 & 340.7 & 5.4 \\
\hline Rents & $919,486,633.00$ & 1.4 & 78.1 & 1.2 \\
\hline $\begin{array}{l}\text { Fuel, power and } \\
\text { water }\end{array}$ & $5,565,966,431.20$ & 8.5 & 617.0 & 9.7 \\
\hline $\begin{array}{l}\text { Clothing and } \\
\text { footwear }\end{array}$ & $4,182,431,247.73$ & 6.4 & 310.3 & 4.9 \\
\hline $\begin{array}{l}\text { Furniture and } \\
\text { household } \\
\text { equipment }\end{array}$ & 1,388,138,393.11 & 2.1 & 103.7 & 1.6 \\
\hline $\begin{array}{l}\text { Household } \\
\text { operation and } \\
\text { maintenance }\end{array}$ & $1,397,441,762.63$ & 2.1 & 155.7 & 2.5 \\
\hline $\begin{array}{l}\text { Personal care } \\
\text { and health }\end{array}$ & $1,411,252,433.38$ & 2.1 & 139.7 & 2.2 \\
\hline $\begin{array}{l}\text { Recreation and } \\
\text { entertainment }\end{array}$ & $543,948,208.36$ & 0.8 & 21.6 & 0.3 \\
\hline Transportation & $6,370,827,117.10$ & 9.7 & 304.1 & 4.8 \\
\hline Education & $1,697,213,836.60$ & 2.6 & 75.3 & 1.2 \\
\hline $\begin{array}{c}\text { Miscellaneous } \\
\text { goods and } \\
\text { services }\end{array}$ & $980,128,387.15$ & 1.5 & 53.3 & 0.8 \\
\hline TOTAL & $65,749,059,778.45$ & 100.0 & $6,352.0$ & 100.0 \\
\hline
\end{tabular}

Source: Calculated from the National Household Budget Survey 
The weights accorded to the consumption component under Fuel, Power and Water is seemingly confounding in that democratic weight is higher than the plutocratic weight for this component. On first sight, one would expect the poor to consume less of Fuel, Power and Water than the rich and also that the budgetary share for this component would be expected to be significantly lower for the poor. Upon examining the data it was found that the category of Fuel, Power and Water includes a very significant share of charcoal, which is the main source of fuel to poor households in the urban areas. The weight of Fuel, Power and Water is 9.5, and out of this 5.1 is accounted for by charcoal alone. Since the data is exclusive from the urban centres it is no wonder that the share of charcoal is so large, virtually all poor households use charcoal for cooking, while the few rich households use electricity or the gas. It is therefore no wonder that this category of consumption is significantly more important, in relative terms, in the household budget of the poor in urban areas, and that the democratic weight accord it more relative importance than does the plutocratic weights.

The share for rent is not overly different between the plutocratic approach and the democratic approach. On first sight, this looks rather strange; one would expect the rich to live in houses that are more expensive than the poor, and therefore one would expect a more pronounced difference between the plutocratic weight and democratic weight for the rent. The reason for the two not being very different might be the following. First the rent is recorded only for houses that are actually rented; own houses are excluded even though the household budget survey records imputed rent. In most cases it is the rich households that live in their own houses; the poor own no houses and therefore pay rent for accommodation. If imputed rent was included it is likely that plutocratic weight for rent would have been significantly higher than its corresponding democratic weight.

The difference between the rich and the poor as reflected in the plutocratic weights is pronounced when one compares the consumption of the poorest ten percent against that of the richest ten percent. Figure 2 below shows the dramatic differences in these weights; while the food weight for the $10 \%$ richest household is 44.7 , that of the $10 \%$ poorest is at the staggering 71.2 . The weight for expenditure on recreation and entertainment for the $10 \%$ richest is 37 times the weight of the same category for the $10 \%$ poorest. Clearly this shows that plutocratic weight is overly biased towards the consumption pattern of rich households. 
Figure 2: Plutocratic Weights: 10\% Richest Households vs 10\% Poorest Households

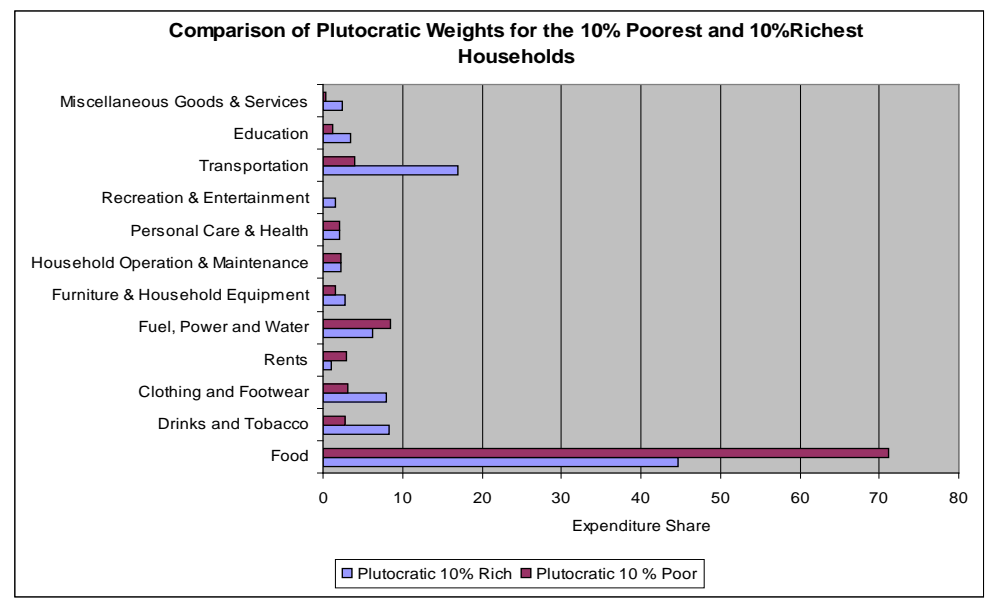

Sources: Calculate from the Household Budget Survey Data

Table 4 compares democratic weights to plutocratic weights for major consumption groups in Tanzanian's CPI for the $10 \%$ richest households. The democratic weight for food (food share) is higher by about $25 \%$ than the plutocratic weight. This shows that the use of plutocratic weight would "underestimate" the weight of food, a consumption component which has higher relative importance to the poor than to the rich. Similarly, the weight that democratic scheme accorded to Recreation and Entertainment is half that of the plutocratic scheme and Education is equally given more weight by the plutocratic scheme as compared to the democratic scheme. It is obvious that the use of plutocratic weight favours consumption items which are of more relative budgetary importance to the rich, while democratic weights favour items that are of more relative budgetary importance to the poor.

Table 4: Democratic and Plutocratic Weights for the 10\% Richest Households

\begin{tabular}{lcc}
\hline \multicolumn{1}{c}{ ITEM } & $\begin{array}{c}\text { DEMOCRATIC } \\
\text { WEIGHT }\end{array}$ & $\begin{array}{c}\text { PLUTOCRATIC } \\
\text { WEIGHT }\end{array}$ \\
\hline Food & 55.7 & 44.7 \\
Drinks and tobacco & 8.1 & 8.3 \\
Rents & 1.4 & 1.0 \\
Fuel, power and water & 7.8 & 6.3 \\
Clothing and footwear & 6.1 & 8.0 \\
$\begin{array}{l}\text { Furniture and household } \\
\text { equipment }\end{array}$ & 2.2 & 2.8 \\
$\begin{array}{l}\text { Household operation and } \\
\text { maintenance }\end{array}$ & 2.6 & 2.3
\end{tabular}


Personal care and health

Recreation and

entertainment

Transportation

Education

Miscellaneous goods and services
2.5

0.7

9.7

1.4

1.7

100.0
2.1

1.5

17.0

3.4

2.5

\begin{tabular}{lll}
\hline TOTAL & 100.0 & 100.0
\end{tabular}

Source: Calculated from the Household Budget Survey Data

Both plutocratic and democratic weights are also calculated for the richest ten percentile, and results are reported in Table 4. Over all, the weight given to the food item is less than that obtained for the national average of 55.9 and 65.4 for plutocratic and democratic weights, respectively. The most dramatic difference is with respect to three consumption groups namely Education, Recreation and Entertainment and Transport, where plutocratic scheme gives about twice the magnitude of weight that democratic scheme gives.

Table 5: Democratic and Plutocratic Weights for the Poor and Non-Poor

\begin{tabular}{lcccc}
\hline WEIGHT SCHEME $\Rightarrow$ & \multicolumn{2}{c}{ DEMOCRATIC } & \multicolumn{2}{c}{ PLUTOCRATIC } \\
\hline CONSUMPTION GROUP $\Downarrow$ & Non Poor & Poor & Non Poor & Poor \\
\hline Food & 63.9 & 68.9 & 54.4 & 65.4 \\
Drinks and Tobacco & 6.1 & 3.7 & 7.7 & 5.4 \\
Clothing and Footwear & 5.4 & 3.7 & 7.0 & 4.9 \\
Rents & 1.2 & 1.2 & 1.2 & 1.2 \\
Fuel, Power and Water & 9.1 & 11.0 & 7.8 & 9.7 \\
Furniture \& Household & 1.8 & 1.2 & 2.3 & 1.6 \\
Equipment & 2.4 & 2.5 & 2.1 & 2.5 \\
Household Operation \& & 2.2 & 2.1 & 2.2 & 2.2 \\
Maintenance & 0.4 & 0.2 & 0.9 & 0.3 \\
Personal Care \& Health & 5.1 & 4.0 & 9.9 & 4.8 \\
Recreation \& Entertainment & 1.1 & 1.3 & 2.8 & 1.2 \\
Transportation & 1.0 & 0.5 & 1.7 & 0.8 \\
Education & & & & \\
Miscellaneous Goods \& & Services & & &
\end{tabular}

Source: Calculated from the Household Budget Survey Data.

Finally the households were divided into poor and non-poor using the official poverty line, and both democratic and plutocratic weights calculated for the twelve major 
consumption groups. This is reported in Table 5. Both democratic and plutocratic weights for food items are higher for the poor than for the rich; the weight for Drinks and Tobacco as well as the Recreation and Entertainment are higher for the rich than for the poor. The main exception to the pattern here is the relative share of education budget; the poor in the democratic weights have relatively more budgetary share than the non-poor.

\section{The Plutocratic Gap in Tanzania: Empirical Results}

Table 6 reports annual inflation for Tanzania from 2003 to 2006 both for plutocratic and democratic weight. Further, annual inflation rate is calculated for households that are below the official poverty line and compared to inflation for household above poverty line, and this is done for both plutocratic and democratic weights. The mean annual "plutocratic" inflation is 5.6 while the mean annual "democratic" inflation is 8.3. The inflation rate using democratic weight is therefore about $50 \%$ higher than the plutocratic inflation.

Inflation is also calculated for poor households only and the annual mean "democratic" inflation is still higher than the annual mean "plutocratic inflation; the former is of order 8.175 while the later is 4.75 . This difference between "plutocratic" inflation and "democratic" inflation is also reflected in the comparison of inflation for households that are above the poverty line.

To gain further insight into the plutocratic gap in Tanzania we use monthly CPI data in which more observations exist for the base year of 2001, and therefore there are sufficient degrees of freedom to conduct tests of significance. Monthly inflation based on both plutocratic weights and democratic weights is plotted in Figure 3.

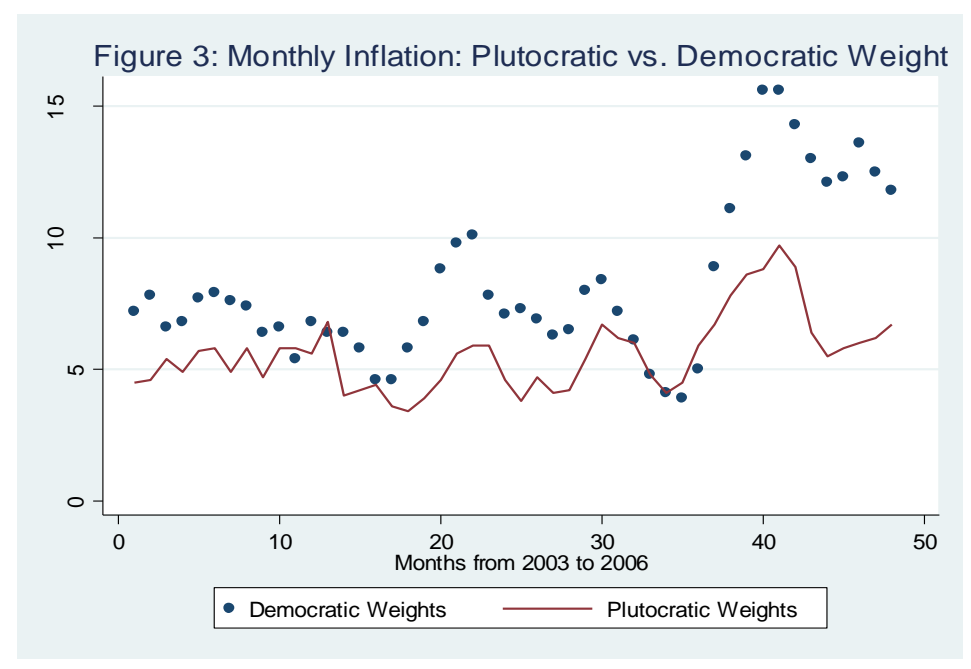

Source: Household Budget Survey Data 
Table 6: Annual Inflation; Plutocratic Vs Democratic

\begin{tabular}{|c|c|c|c|c|}
\hline Weight Scheme $\Downarrow$ Year $\Rightarrow$ & 2003 & 2004 & 2005 & 2006 \\
\hline Plutocratic Inflation & 5.3 & 4.7 & 5.0 & 7.3 \\
\hline Democratic Inflation & 7.0 & 7.1 & 6.2 & 12.8 \\
\hline Plutocratic Inflation (The Poor) & 3.2 & 5.4 & 4.8 & 5.6 \\
\hline Democratic Inflation (The Poor) & 7.9 & 6.5 & 5.5 & 12.8 \\
\hline $\begin{array}{l}\text { Plutocratic Inflation (The Non- } \\
\text { Poor) }\end{array}$ & 3.7 & 4.8 & 5.4 & 7.9 \\
\hline $\begin{array}{l}\text { Democratic Inflation (The Non- } \\
\text { Poor) }\end{array}$ & 7.6 & 6.6 & 5.8 & 12.8 \\
\hline
\end{tabular}

Source: Calculated from the Household Budget Survey Data

The annual figures shows that "democratic" inflation is higher than "plutocratic" inflation, but this does not necessarily mean that the difference is statistically significant, and given the paucity of the sample size no test of significance can be done to assess whether the difference is significant or not.

To test for the significance of this difference we employ the z-statistics on two monthly inflation rates. Assume that the mean monthly "democratic" inflation is given by $\mu_{\mathrm{D}}$ and the mean monthly "plutocratic" inflation is $\mu_{\mathrm{p}}$. Assume that the difference between the two means is given by $D=\mu_{D}-\mu_{P}$ and is obtained from a population with normal distribution. Let the null and alternative hypotheses be defined as follows:

$$
\begin{aligned}
& H_{0}: D=0 \\
& H_{1}: D \neq 0
\end{aligned}
$$

The test statistics for the pair-observations is given as follows:

$$
z=\frac{\bar{D}-D}{s_{D} / \sqrt{n}}=\frac{\bar{D}-0}{s_{D} / \sqrt{n}}
$$

where $\bar{D}$ is the sample average difference between each pair of inflation series, $\mathrm{s}_{\mathrm{D}}$ is the sample standard deviation of the differences and $n$ is the sample size of the two series. Applying this test for the difference between plutocratic monthly inflation and democratic monthly inflation gives a value of $z$ that is -8.481994 , which is far below the critical value of -1.96 . The null hypothesis is therefore rejected; the mean value of plutocratic inflation is not equal to the mean value of democratic inflation. In fact, democratic inflation is greater than the plutocratic inflation, given the fact that the rejection region is to the left side of the two tail test. This confirms that the difference between the two series of inflation in Figure 3 is significant. 
Next, we investigate whether democratic inflation registers rates that are significantly different between the poor and the non-poor. Figure 4 suggest that the difference between the inflation rate faced by the poor and the one faced by the non-poor is not significantly different once inflation is calculated using CPI with democratic weights. The calculated z-value is -0.023037 , which is within the non-rejection region. We cannot therefore reject the null hypothesis that inflation rates for the poor and nonpoor has equal mean for the democratic weighted CPI.

Figure 4: Democratic Monthly Inflation: Poor vs. Non Poor

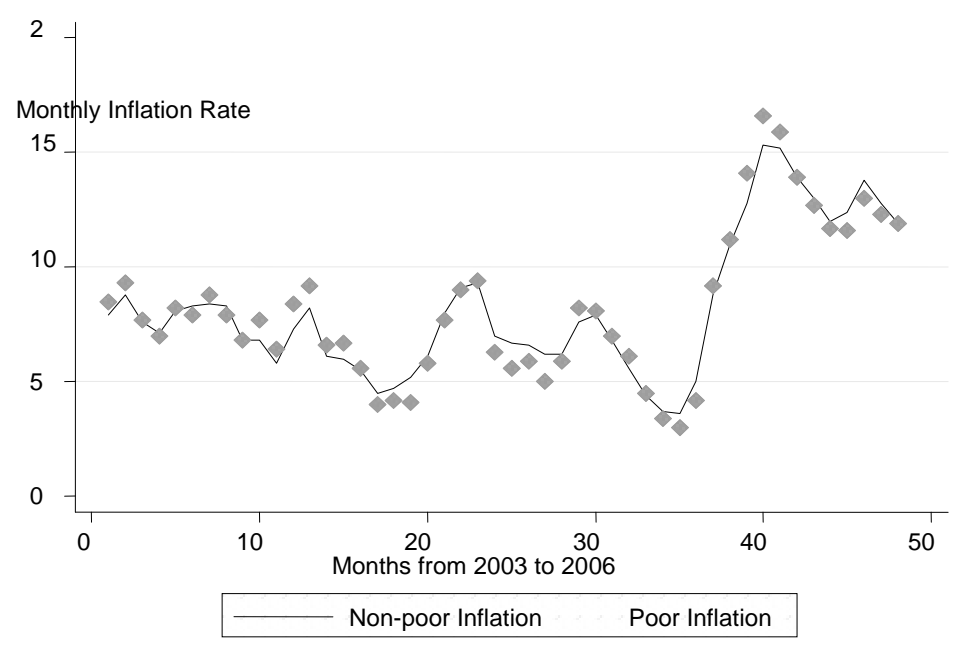

Source: Household Budget Survey Data

It is significant that democratic weighted CPI produces inflation that is statistically invariant to whether households are poor or not poor. To find out whether plutocratic weighted CPI produce similar results a plot of plutocratic inflation for the poor and non-poor is reported in Figure 5. Because the scatter of the two series turn out not to be very revealing, a lowess smoothing technique is used to generate smooth series. The graph suggests that plutocratic inflation for the poor tends to be higher than plutocratic inflation for non-poor.

It is noteworthy that democratic method of weighting the CPI minimizes the difference in the inflation rates that the poor and the non-poor faces. This feature is not enjoyed by the CPI based on plutocratic weighting method. This fact, together with the fact that democratic weighted CPI is more sensitive to the inflation faced by the poor seems to suggest that democratic weighting is better than plutocratic weights.

Upon applying statistical tests for the difference in the mean of the plutocratic inflation for the poor against the plutocratic inflation for the non-poor the z-value is found to be -3.705348, which leads to the rejection of the null hypothesis that the two series have similar means. 


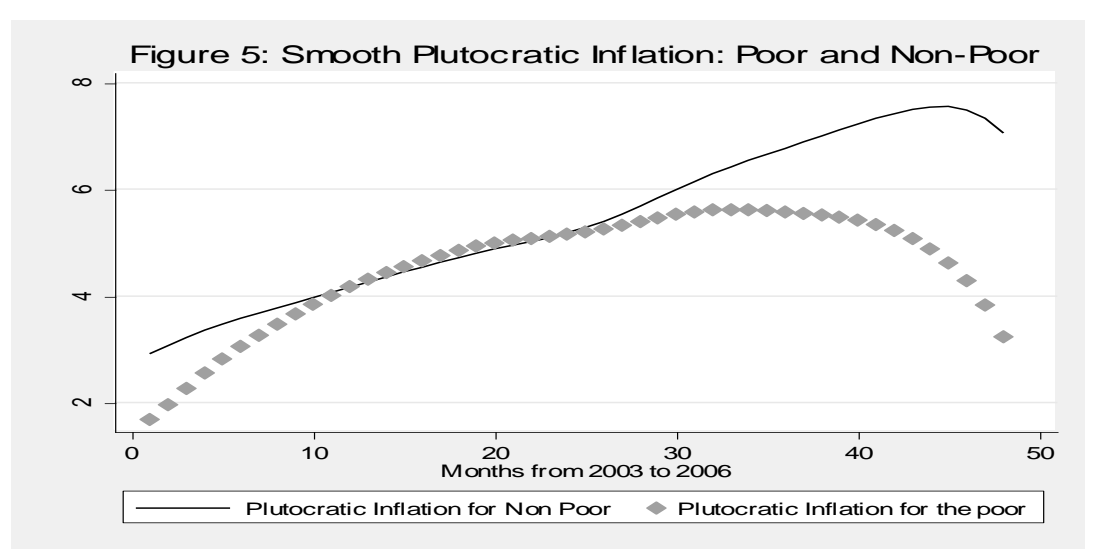

Source: Household Budget Survey Data

\section{Conclusion}

This paper set out to investigate the difference between inflation rates based on the "plutocratic" weighted CPI and one based on "democratic" weighted CPI using Tanzanian data. The finding is that there is a marked difference between the two inflation rates. In particular, democratic inflation is found to be more pro-poor than plutocratic inflation rate. Even though it is argued that no normative significance should be attached to the plutocratic gap, it is obvious that a "democratic weighted" inflation would make national policy on inflation more sensitive to the harm that inflation inflicts to the poor than the plutocratic weighed inflation. It would be better therefore if countries replace the "plutocratic weighing scheme" which is currently the standard scheme for CPI in favour of democratic weighting scheme. This is particularly important to poor countries in Africa and beyond where poverty reduction is an overriding policy objective.

\section{Reference}

Aizorbe Ana M. and Patric C. Jackman (1993), “The Commodity Substitution Effect in CPI Data, 1982-1991”, Monthly Labour Review, December. 25-33.

Amble Nathan and Ken Stewart (1994), "Experimental Price Indices for Elderly Consumers”, Monthly Labour Review, May. 11-16.

Arrow Kenneth J. (1958) “The Measurement of Price Changes”, in The Relationship of Prices to Economic Stability and Growth. Joint Economic Committee US Congress, March 31.

Boskin M. and Hurd M. (1985) "Indexing Social Security Benefits: A Separate Price Index for the Elderly”, Public Finance Quarterly, 13. 436-449.

Boskin Michael J, Dulberger, Ellen R, Gordon Robert J, Griliches Zvi and Dale W. 
Jorgen (1998) "Consumer Prices, the Consumer Price Index, and the Cost of

Living” The Journal of Economic Perspectives, Vol. 12, No.1 pp.3-26

Crawford I. and Z. Smith (2002), “Distributional Aspects of Inflation”, The Institute for Fiscal Studies. June.

Diewert W. Erwin (1976) “Exact and Superlative Index Numbers”, Journal of Econometrics, May 4. 115-145.

Diewert,Erwin W (2001), “The Consumer Price Index and index number purpose”, Journal of Economic and Social Measurement 27,167-248 167

Drakopolous Stavros A. (1992), "Keynes Economic Thought and the Theory ofConsumer Behaviour” Scottish Journal of Political Economy, 39(3). 318336.

Easterly William and Stanely Fischer (2000), "Inflation and the Poor", World Bank Policy Research Working Paper No. 2335.

Garner Thesla I., David S. Johnson and Mary F. Kokoski (1996), “An Experimental Consumer Price Index for the Poor”. Monthly Labour Review, September. 3242.

Greenlees John S. (2001), “Random Errors and Superlative Indexes”. BLS Working Papers, US Department of Labour, Working Paper 343, March.

Griliches, Zvi, (1995), “Prepared Statement,” in Consumer Price Index: Hearings Before the Committee on Finance, U.S. Senate, Senate Hearing 104-69 (Washington: Government Printing Office), pp. 129-32.

Hagemann Robert (1982), “The Variabilility of Inflation Rates across Household Types”, Journal of Money, Credit and Banking, November. 494-510.

Hausman Jerry (2002), "Sources of Bias and Solutions to Bias in the CPI”, NBER Working Paper, No. 9298.

Hulten, Charles R (2004) “The Political Economy of Price Measurement: The NAS Report “At What Price” and Beyond”, University of Maryland and the National Bureau of Economic Research.

Idson Todd and Cynthia Miller (1999), “Calculating a Price Index for Families with Children: Implications for Measuring Trends in Child Poverty Rates”, Working Paper, Columbia University Server Project, June.

Izquierdo, M, Eduardo Ley, and Javier Ruiz-Castillo (2003), “The Plutocratic Gap in the CPI: Evidence from Spain”, IMF Staff Papers, Vol. 50, No. 1, International Monetary Fund

Jorgenson D.W. and D.T. Slesnick (1983) "Individual and Social Cost of Living Indexes”, in Price Level Measurement, eds W.E. Diewert and C.Montmarquette, Ottowa: Statistics Canada, pp 241-336.

Kokoski, Mary F., (2000), “Alternative CPI Aggregations: Two Approaches,” BLS 
Monthly Labor Review, U.S. Bureau of Labor Statistics, Vol. 123, No. 11, pp. 31-39.

Laspeyres Price Index: Ireland, 1985-2001”,. The Economic and Social Review, Vol. 35 Spring. 55-82.

Lavoie Marc (1992), "Foundations of Post-Keynesian Economic Analysis", Aldershot, Edward Elgar.

Lavoie Marc (1994) “A Post-Keynesian Approach to Consumer Choice”, Journal of Post-Keynesian Economics, 16 (4). 539-562.

Ley, Eduardo, (2002), "Whose Inflation?: A Characterization of the CPI Plutocratic Gap” (Washington: IMF Institute), http://econwpa.wustl.edu/eprints/pe/ papers/0110/0110001.abs.

Lorenzo, Fernando, (1998), “Modelización de la inflación con fines de predicción y diagnóstico”, (Ph.D. dissertation; Madrid: Universidad Carlos III de Madrid).

Madden David (1993), “A New Set of Consumer Demand Estimates for Ireland”, The Economic and Social Review, Vol. 24. No. 2, January. 101-123.

Madrick, Jeff, (1997a), “The Cost of Living: A New Myth,” New York Review of Books (March 6).

__ (1997b), “Cost of Living: An Exchange,” New York Review of Books (June 26).

McCarthy, Colm (1977) "Estimates of a System of Demand Equations using Alternative Commodity Classifications of Irish Data, 1953-1974”, The Economic and Social Review. Vol. 8. no. 3, 201-211.

Michael Robert (1979), "Variation across Households in the Rate of Inflation", Journal of Money, Credit and Banking, 32-46.

Moulton Brent R. (1996) 'Bias in the Consumer Price Index: What is the Evidence?' Journal of Economic Perspectives, Fall 10(4), 159-177.

Muellbauer, John, (1976), “The Political Economy of Price Indices,” Birkbeck Discussion Paper No. 22 (London: Birkbeck College).

National Research Council, (1995), “Measuring Poverty: A New Approach”, Washington: National Academy Press.

Newberry, David M., (1995), “The Distributional Impact of Price Changes in Hungary and the United Kingdom,” Economic Journal, Vol. 105 (July), pp. 847-63.

Nicholson, J.L., (1975), “Whose Cost of Living?”, Journal of the Royal Statistical Society, Series A, Vol. 138, No. 4, pp. 540-42.

Pollak, Robert, (1980), “Group Cost-of-Living Indexes,” American Economic Review, Vol. 70, No. 2, pp. 273-78. 
Pollak, Robert, (1998), "The Consumer Price Index: A Research Agenda and Three Proposals,” Journal of Economic Perspectives, Vol. 12, No. 1, pp. 69-78.

Prais, Sigbert J., (1959), “Whose Cost of Living?” Review of Economic Studies, Vol. 26, pp. 126-34

Renwick Trudi J. (1998), "Does the U.S. Consumer Price Index Overestimate the Changes in the Cost of Living for Low-Income Families?” Feminist Economics Fall 4(3) pp. 129-142.

Ruiz-Castillo, Javier, Eduardo Ley, and Mario Izquierdo, (1999), "La Medición de la Inflación en España”, (Barcelona: Caja de Ahorros y Pensiones de Barcelona).

— , (2002a), "Distributional Aspects of the Quality Change Bias in the CPI: Evidence from Spain,” Economics Letters, Vol. 76 (June), pp. 137-44.

_ (2002b), "The Laspeyres Bias in the Spanish CPI," Applied Economics, Vol. 34 (December), pp. 2267-76

Sen Amartya (1999), “Development as Freedom”, Oxford.

Senate Finance Committee (1996), "Advisory Commission to Study the Consumer Price Index, Toward a more Accurate Measure of the Cost of Living", December 4. Somerville R.A. (2004) "Changes in Relative Consumer Prices and the Substitution Bias of the

Schultze, Charles L., and Christopher Mackie, eds., (2002), "At What Price? Conceptualizing and Measuring Cost-of-Living and Price Indexes", Panel on Conceptual, Measurement, and Other Statistical Issues in Developing Costof-Living Indexes (Washington: Committee on National Statistics, National Research Council).

Slesnick, Daniel T., (1991), "The Standard of Living in the United States," Review of Income and Wealth, Vol. 37, pp. 363-86.

Snyder Eleanor (1961), "Cost of Living Indexes for Special Classes of Consumers”, The Price Statistics of the Federal Government: Review, Appraisal and Recommendations. A Report to the Office of Statistical Standards, Bureau of the Budget (NEBR), Staff Paper 7.

Triplett, Jack E., 1983, "Escalation Measures: What Is the Answer, What Is the Question?” in Price Level Measurement, ed. by W.E. Diewert and C. Montmarquette (Ottawa: Minister of Supply and Services, Canada), pp. 45782.

URT (United Republic of Tanzania)(2002) Household Budget Survey 2000/01: Final Report. Dar es Salaam: National Bureau of Statistics. 
Appendix 1: Tanzania's Deviation from COICOP

\begin{tabular}{|c|c|c|}
\hline $\begin{array}{l}\text { Group } \\
\text { Number }\end{array}$ & $\begin{array}{l}\text { Consumer Price Index (Cpi) - } \\
\text { Tanzania Classification }\end{array}$ & $\begin{array}{l}\text { Un Classification Of Individual } \\
\text { Consumption By Purpose (Coicop) }\end{array}$ \\
\hline 1 & $\begin{array}{l}\text { Food } \\
\text { This group consists of Food and } \\
\text { Catering Services while Catering } \\
\text { Services is in group 11(Restaurants } \\
\text { and Hotels) of UN COICOP. } \\
\text { Beer from bars and restaurants is } \\
\text { excluded in this group but captured } \\
\text { in group } 2 \text { (Drinks and Tobacco) of } \\
\text { TZ Classification }\end{array}$ & $\begin{array}{l}\text { Food and Non Alcoholic Beverages } \\
\text { This group consists of Food and } \\
\text { Non Alcoholic Beverage where by } \\
\text { Alcoholic Beverage is in group } 2 \\
\text { of TZ Classification (Drinks and } \\
\text { Tobacco) }\end{array}$ \\
\hline 2 & $\begin{array}{l}\text { Drinks and Tobacco } \\
\text { This group consists of Non } \\
\text { Alcoholic Beverages borrowed } \\
\text { from (Group } 1 \text { of UN COICOP) } \\
\text { plus Alcoholic Beverages and } \\
\text { Tobacco. }\end{array}$ & $\begin{array}{l}\text { Alcoholic, Tobacco and Narcotics } \\
\text { Group } 2 \text { of UN COICOP consists of } \\
\text { Alcoholic Beverages and Tobacco. }\end{array}$ \\
\hline 3 & $\begin{array}{l}\text { Clothing and Footwear } \\
\text { Includes clothing and clothing } \\
\text { materials but excluding School } \\
\text { Uniforms which are in group } 11 \\
\text { (Education) }\end{array}$ & $\begin{array}{l}\text { Clothing and Footwear } \\
\text { This group consists of clothing and } \\
\text { clothing materials. School Uniforms } \\
\text { is also included here borrowed } \\
\text { from group } 11 \text { (Education) of } \mathrm{TZ} \\
\text { Classification }\end{array}$ \\
\hline 4 & $\begin{array}{l}\text { Rent } \\
\text { Group } 4 \text { of Tanzania classification } \\
\text { consists of only one item of Actual } \\
\text { Rent paid per room }\end{array}$ & $\begin{array}{l}\text { Housing, Water, Electricity, Gas } \\
\text { and Other Fuel } \\
\text { Group } 4 \text { of UN COICOP apart from } \\
\text { Actual Rent, it includes items of } \\
\text { utilities, water, electricity, gas and } \\
\text { other fuel. }\end{array}$ \\
\hline 5 & $\begin{array}{l}\text { Fuel, Power and Water } \\
\text { This group has been completely } \\
\text { absolved into group } 4 \text { of UN } \\
\text { COICOP }\end{array}$ & $\begin{array}{l}\text { Furnishing, Housing Equipment } \\
\text { and Routine Maintenance of the } \\
\text { House } \\
\text { Group } 5 \text { of UN COICOP is a } \\
\text { combination of items from group } \\
6 \text { (Furniture and Household } \\
\text { Equipments) and } 7 \text { (Household } \\
\text { Operations and Maintenance) from } \\
\text { Tanzania Classification }\end{array}$ \\
\hline 6 & $\begin{array}{l}\text { Furniture and Household } \\
\text { Equipments } \\
\text { Moved to Group } 5 \text { (Furnishing, } \\
\text { Housing Equipment and Routine } \\
\text { Maintenance of the House) of UN } \\
\text { COICOP }\end{array}$ & $\begin{array}{l}\text { Health } \\
\text { This group has been chopped from } \\
\text { group } 8 \text { (Personal Care and Health) } \\
\text { of Tanzania Classification }\end{array}$ \\
\hline
\end{tabular}




\begin{tabular}{|c|c|c|}
\hline 7 & $\begin{array}{l}\text { Household Operations and } \\
\text { Maintenance } \\
\text { Moved to Group } 5 \text { (Furnishing, } \\
\text { Housing Equipment and Routine } \\
\text { Maintenance of the House) of UN } \\
\text { COICOP }\end{array}$ & $\begin{array}{l}\text { Transport } \\
\text { This group has been chopped } \\
\text { from group } 10 \text { (Transportation) of } \\
\text { Tanzania Classification }\end{array}$ \\
\hline 8 & $\begin{array}{l}\text { Personal Care and Health } \\
\text { This group has been distributed } \\
\text { into group } 6 \text { (Health) and } 12 \\
\text { (Miscellaneous Goods and } \\
\text { Services)of UN COICOP }\end{array}$ & $\begin{array}{l}\text { Communication } \\
\text { This group include some items from } \\
\text { group } 12 \text { (Miscellaneous Goods \& } \\
\text { Services) of Tanzania Classification }\end{array}$ \\
\hline 9 & $\begin{array}{l}\text { Recreation and Entertainment } \\
\text { This Group is a subset of Group } \\
9 \text { (Recreation and Culture) of UN } \\
\text { COICOP }\end{array}$ & $\begin{array}{l}\text { Recreation and Culture } \\
\text { The same as group } 9 \text { (Recreation and } \\
\text { Entertainment) of TZ Classification } \\
\text { but is more detailed }\end{array}$ \\
\hline 10 & $\begin{array}{l}\text { Transportation } \\
\text { This group has been completely } \\
\text { absolved into group } 7 \text { (Transport) } \\
\text { of UN COICOP }\end{array}$ & $\begin{array}{l}\text { Education } \\
\text { This is the same as Group } \\
11 \text { (Education) of Tanzania } \\
\text { classification but more detailed }\end{array}$ \\
\hline 11 & $\begin{array}{l}\text { Education } \\
\text { This group has been completely } \\
\text { absolved into group } 10 \text { (Education) } \\
\text { of UN COICOP, it also include } \\
\text { School uniforms which are in group } \\
3 \text { (Clothing and Footwear) of UN } \\
\text { COICOP }\end{array}$ & $\begin{array}{l}\text { Restaurants and Hotels } \\
\text { Group } 11 \text { of UN COICOP items } \\
\text { were chopped from three groups of } \\
\text { Tanzania classification i.e. 1, } 2 \text { and } \\
12\end{array}$ \\
\hline 12 & $\begin{array}{l}\text { Miscellaneous Goods \& Services } \\
\text { This group include items from } \\
\text { group } 8 \text { (Communication) and } 11 \\
\text { (Restaurants and Hotels) of UN } \\
\text { COICOP }\end{array}$ & $\begin{array}{l}\text { Miscellaneous Goods and Services } \\
\text { This has been formed from group } 8 \\
\text { and } 12 \text { of Tanzanian classification i.e. } \\
\text { (Personal care and Personal Effects } \\
\text { respectively) but is more detailed }\end{array}$ \\
\hline
\end{tabular}

